\title{
A CRITIQUE OF THE LAFFER CURVE
}

\author{
EDWARD W. FULLER
}

Fecha de recepción: 30 de abril de 2020

Fecha de acpetación: 9 de septiembre de 2020

In December 1974, the economist Art Laffer had dinner at a Washington D.C. restaurant with Jude Wanniski, Donald Rumsfeld, and Dick Cheney. The tax rate was so high in the United States, Laffer argued, that reducing the tax rate would increase government tax revenue. As legend has it, he drew the Laffer Curve on a napkin to illustrate how reducing the tax rate would raise tax revenue. The Laffer Curve has been a mainstay of Supply-Side Economics ever since.

The Laffer Curve relates government tax revenue to the tax rate. Figure 1 is the Laffer Curve (Laffer, 2004). The x-axis shows tax revenue and the $y$-axis shows the tax rate. The Laffer Curve plots the relationship between the tax rate and tax revenue. As figure 1 shows, tax revenue is maximized, or optimal at $\mathrm{RO}$, when the tax rate is $\mathrm{TO}$.

FIGURE 1: LAFFER CURVE

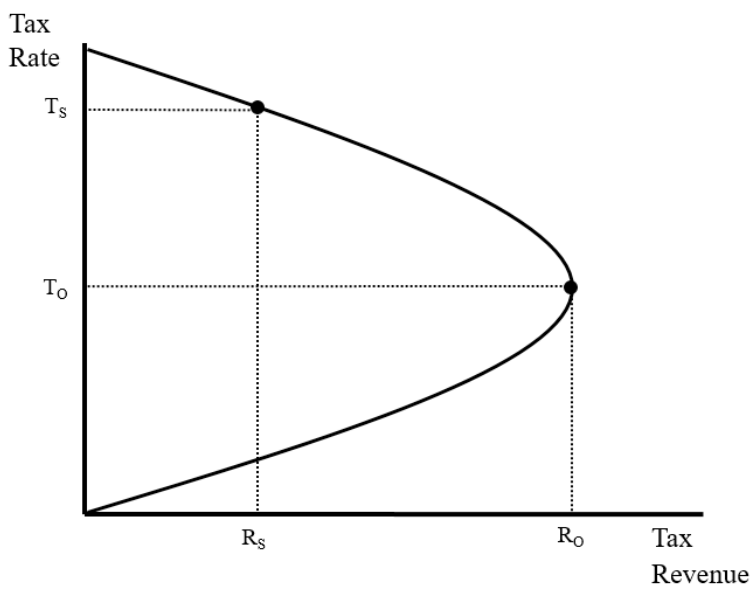


Further, the Laffer Curve illustrates that tax revenue decreases as the tax rate rises above the optimal tax rate. For example, imagine the tax rate is suboptimal at TS. At this tax rate, government revenue is suboptimal at RS. Even though the tax rate TS is higher than TO, tax revenue RS is actually lower than RO. In this case, government can increase tax revenue by reducing the tax rate. Generally, government can increase tax revenue by lowering the tax rate whenever the economy is located on the downward sloping part of the Laffer Curve. In short, the Laffer Curve suggests that extremely high taxes are counterproductive even from the government's own perspective.

Murray N. Rothbard stressed that Laffer's analysis contains a hidden value judgement: maximizing government tax revenue is desirable. Rothbard writes,

"Laffer assumes that what all of us want is to maximize tax revenue to the government. If-a big if-we are really at the upper half of the Laffer curve, we should then all want to set tax rates at that "optimum" point. But why? Why should it be the objective of every one of us to maximize government revenue? To push to the maximum, in short, the share of private product that gets siphoned off to the activities of government? I should think we would be more interested in minimizing government revenue by pushing tax rates far, far below whatever the Laffer Optimum might happen to be" (Rothbard, 1984: 17-18; Block, 2010).

Economists who use the Laffer Curve conduct their analysis with a fixed curve. However, in a progressing economy, the Laffer Curve is constantly expanding. Put differently, the Laffer Curve is always shifting to the right in a progressing economy. Advocates of the Laffer Curve fail to realize that the position of the curve is far more important than the economy's place on a given curve.

The position of the Laffer Curve depends on the stock of accumulated capital. As economists underscore again and again, capital accumulation is the only way to raise overall living standards. Ludwig von Mises writes,

"there is but one method available to improve the conditions of the whole population, viz., to accelerate the accumulation of capital as against the increase in population. The only method of rendering all people more prosperous is to raise the productivity of human 
labor, i.e., productivity per man hour, and this can be done only by placing into the hands of the worker more and better tools and machines." (1951: 282)

Significantly, capital accumulation and hence overall living standards depend on the tax rate. As economists have known for centuries, high taxes impair capital accumulation:

"If the funds which the successful businessmen would have ploughed back into productive employments are [taxed and] used by the state for current expenditure or given to people who consume them, the further accumulation of capital is slowed down or entirely stopped. Then there is no longer any question of economic improvement, technological progress, and a trend toward higher average standards of living" (Mises, 1955: 51).

To illustrate, consider the Capital Accumulation Curve as shown in Figure 2. The x-axis shows the amount of capital accumulation and the y-axis shows the tax rate. The Capital Accumulation Curve plots the relationship between the tax rate and the amount of capital accumulation. The curve slopes downward, from left to right, meaning the amount of capital accumulation increases as the tax rate falls. Conversely, the amount of capital accumulation decreases as the tax rate increases.

FIGURE 2: CAPITAL ACCUMULATION CURVE

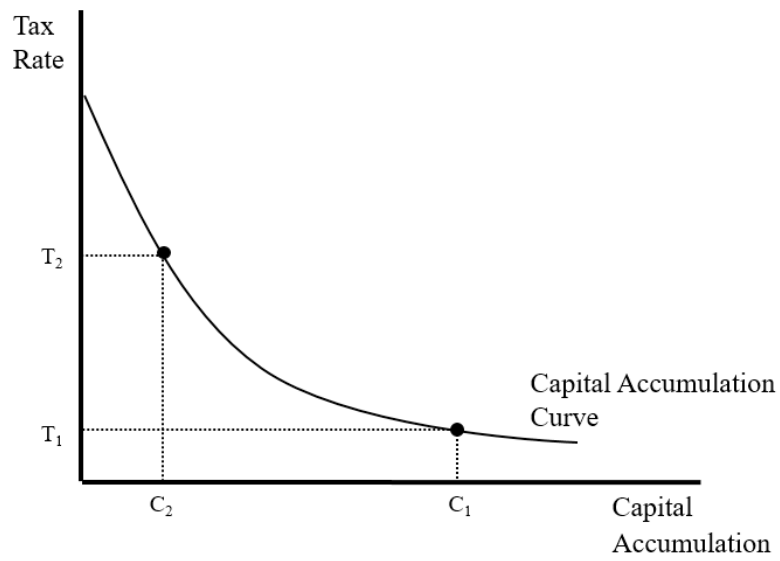


Imagine the tax rate is T1. At this tax rate, the Capital Accumulation Curve shows that the amount of capital accumulation is $\mathrm{C1}$. Now imagine that the tax rate rises to T2. The Capital Accumulation Curve shows that the amount of capital accumulation drops at a higher tax rate, from $\mathrm{C} 1$ to $\mathrm{C} 2$. All this illustrates that, other things being equal, the amount of capital accumulation is higher when the tax rate is lower.

The Capital Accumulation Curve shares the y-axis with the Laffer Curve. Thus, it is possible to link the Laffer Curve and the Capital Accumulation Curve as shown in figure 3. Figure 3 illustrates that the tax rate that maximizes government revenue on the Laffer Curve does not maximize the amount of capital accumulation. The optimal tax rate as suggested by the Laffer Curve maximizes government revenue. But the Laffer optimum is not optimal for capital accumulation. And capital accumulation, not government revenue, is what leads to higher overall living standards.

FIGURE 3: LAFFER CURVE AND CAPITAL ACCUMULATION CURVE

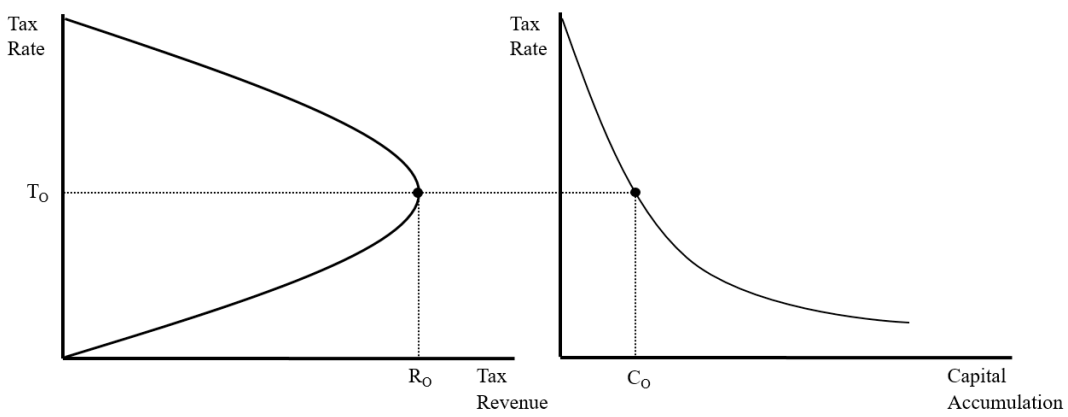

Further, even from the standpoint of government revenue, the optimal tax rate suggested by the Laffer Curve is suboptimal over time. As stressed, the position of the Laffer Curve depends on the stock of accumulated capital. And the Laffer Curve shifts right as capital accumulates. All else equal, a higher tax rate leads to smaller rightward shifts in the Laffer Curve. This is illustrated in figure 4 . The top panels show the shift in the Laffer Curve when 
the tax rate is suboptimal (TS), or lower than the Laffer optimum. The bottom panels show the shift in the Laffer Curve when the tax rate is at the Laffer optimum (TO).

\section{FIGURE 4: LAFFER CURVE EXPANSION}

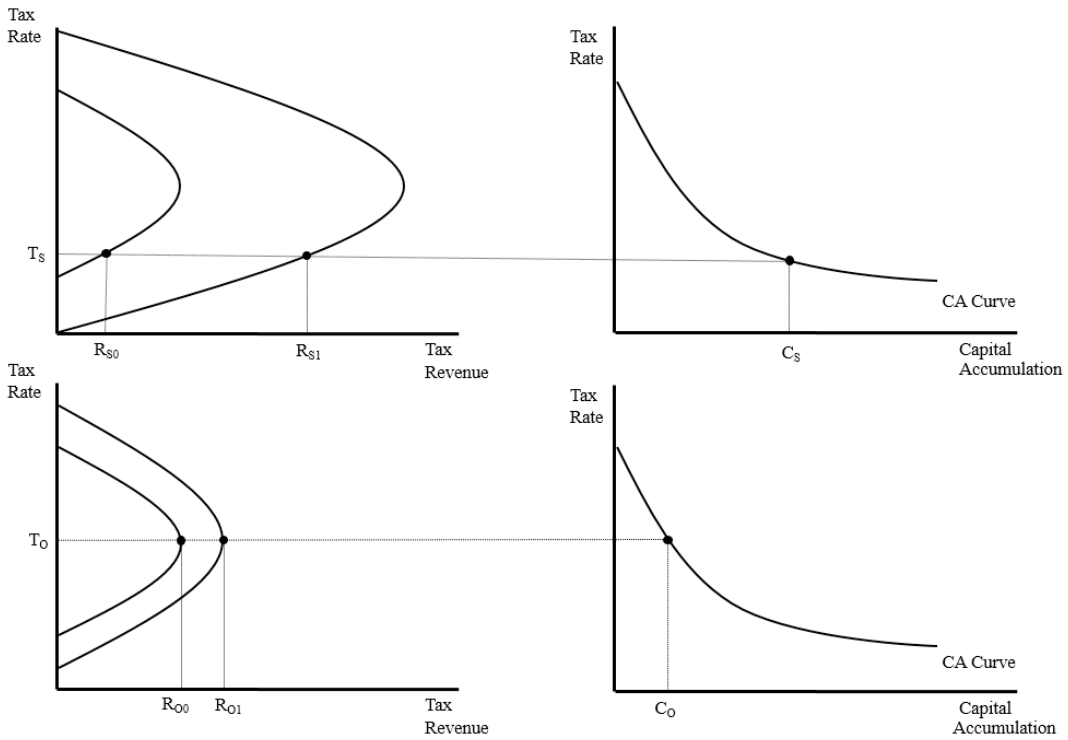

As the bottom-left panel of figure 4 shows, government revenue is $\mathrm{RO} 0$ when the tax rate is set at Laffer's optimal of TO. The upperleft panel shows government revenue is RS0 when the tax rate is below Laffer's optimal at TS. RO0 exceeds RS0, meaning Laffer's optimal tax rate does initially lead to more tax revenue. However, the lower tax rate TS allows for a much larger shift in the Laffer Curve than the optimal rate TO. Once the curves shift, government revenue RS1 is greater than RO1, even though the tax rate is deemed suboptimal. While a higher tax rate initially produces more tax revenue, a lower tax rate leads to higher tax revenue over time.

Those who criticize high taxes on the basis of the Laffer Curve miss the point badly. Advocates of the Laffer Curve maintain that 
extremely high taxes are undesirable because they lead to lower tax revenue. The real economic problem with high taxes is that they arrest capital accumulation. Further, extremely high taxes lead to capital consumption. In terms of the Laffer Curve, capital consumption causes the curve to contract, or shift left. Capital consumption reduces overall living standards, shrinks the tax base, and leads to even lower tax revenue over time. But lower tax revenue is not the real danger of extremely high taxes. The serious economic danger is lower overall living standards brought on by capital consumption.

Laffer's "optimal" tax rate will always be far too high from the standpoint of capital accumulation. As Mises emphasized, "progressive capital formation is the only means by which the position of the great masses can be permanently improved," but "taxation results in checking economic progress and improvement" (1922: 415; 1949: 804).

\section{REFERENCES}

Block, W.E. (2010): “Is There an 'Anomalous' Section of the Laffer Curve?" Libertarian Papers, Vol. 2, no. 6, pp. 1-11.

Laffer, A.B. (2004): “The Laffer Curve: Past, Present, and Future." Backgrounder, no. 1765: pp. 1-16.

Mises, L.V. (1922): Socialism: An Economic and Sociological Analysis. Indianapolis: Liberty

Fund, 1981.

- (1949): Human Action: A Treatise on Economics. Auburn (AL): Ludwig von Mises Institute, 1999.

- (1955): “Inequality of Wealth and Income." In B.B. Greaves (ed.), Economic Freedom and Interventionism, pp. 50-55, Indianapolis: Liberty Fund, 2007.

- (1951): "Some Observations on Current Economic Methods and Policies." In R.M. Ebeling (ed.), Money, Method, and the Market Process, pp. 280-86. Auburn (AL): Ludwig von Mises Institute, 1991.

Rothbard, M.N. 1984. "Ten Great Economic Myths." In Making Economic Sense, pp. 7-19. Auburn (AL): Ludwig von Mises Institute, 2006. 